\title{
Cutaneous Blastomycosis - a case report
}

\author{
Đuka NINKOVIĆ BAROŠ ${ }^{1}$, Jagoda BALABAN ${ }^{*}$, Svetlana TOMAŠEVIĆ PAVLOVIĆ ${ }^{2}$ \\ Aleksandra SALAPURA DUGONJIĆ ${ }^{2}$, Gorana POPOVIĆ ${ }^{1}$, Dušanka BRĐANIN ${ }^{1}$
}

${ }^{1}$ Department of Dermatovenerology, Clinical Center Banja Luka, Republic of Srpska, Bosnia and Herzegovina

${ }^{2}$ Department of Pathology, Clinical Center Banja Luka, Republic of Srpska, Bosnia and Herzegovina

*Correspondence: Jagoda BALABAN, E-mail: jagoda.balaban@yahoo.com

UDC 616.5-022.1:616.992

VERSITA

\begin{abstract}
We present a 46-year-old non-atopic HIV-negative woman from Doboj, Republic of Srpska, Bosnia and Herzegovina, who was referred to the Department of Dermatovenereology, Clinical Center Banja Luka, Republic of Srpska, Bosnia and Herzegovina, with a 3-month long history of an erythematous, large indurated inflamed area on the upper arm. The condition was asymptomatic, immediately following surgical excision of a small tumor. After exlusion of pulmonary blastomycosis and other organ involvement, the diagnosis of primary inoculation cutaneous blastomycosis was made based on clinical presentation and histopathological findings. Histopathology revealed thick-walled, rounded, budding yeasts with broad-based buds that stained pink with periodic acid-schiff (PAS) staining. Itraconazole therapy was initiated at a dose of $2 \times 100 \mathrm{mg} /$ day. After three months of therapy, the dose of itraconazole was increased to $2 \times 200$ $\mathrm{mg} /$ day during the next three months, and then the dose was reduced to $2 \times 100 \mathrm{mg}$. Blastomycosis is an uncommon, chronic granulomatous and suppurative mycosis caused by Blastomyces dermatitidis, which belongs to the group of main endemic systemic mycoses and in the great majority of cases represents a primary pulmonary disease. Few sporadic cases have been reported in Europe. There are three forms of blastomycosis: primary cutaneous, pulmonary and disseminated. B. dermatitidis has rarely been isolated from the environment. Wood debris or land close to rivers or subject to flooding are considered to be the natural substrate. The fungus can grow in sterile soil in the laboratory, and it is believed that humans get infected by inhaling spores from a saprophytic source. Primary cutaneous blastomycosis is very rare and it is found in farmers and laboratory workers. Human to human transmission does not normally occur. The diagnosis of the skin lesions is made by direct microscopy of skin samples (e.g., pus, scrapings) with $10 \%$ potassium hydroxide mount and confirmed by culture or biopsy. Histopathological analysis provides identification of all the dimorphic fungi. However, this can be complicated by the fact that in some cases they can be morphologically atypical or sterile. In the tissues, B. dermatitidis produces characteristic thick-walled, rounded, refractile, and spherical budding yeasts with broad-based buds. Of the available antimycotic drugs, itraconazole $200 \mathrm{mg} /$ day is probably the most effective, but at least $400 \mathrm{mg} /$ day is redommended initially.
\end{abstract}

\section{Key words}

Blastomycosis; Dermatomycoses; Treatment Outcome; Disease Progression; Itraconazole

$\mathrm{B}$ lastomycosis is an uncommon, chronic granulomatous and suppurative mycosis caused by Blastomyces dermatitidis, which belongs to the group of main endemic systemic mycoses and in the great majority of cases represents a primary pulmonary disease (1). The condition was originally thought to be restricted to the North American continent with sporadic cases in Mexico and Central America.
However, it is now known to be widely distributed in Africa. Few sporadic cases have been reported in Europe. There are three forms of blastomycosis: primary cutaneous, pulmonary and disseminated. $B$. dermatitidis has rarely been isolated from the environment. Wood debris or land close to rivers or subject to flooding are considered to be the natural substrate. The fungus can grow in sterile soil in the 
laboratory, and it is believed that humans get infected by inhaling spores from a saprophytic source. Primary cutaneous blastomycosis is very rare and it mostly occurs as a laboratory or autopsy infection, but it may occur following traumatic inoculation of the fungus into the skin. Primary cutaneous blastomycosis is found in farmers and laboratory workers. Human to human transmission does not normally occur. The fungus has also been recovered from domestic animals (e.g. dogs). Blastomycosis is a common infection among dogs in endemic areas. It may aid as an indicator of human disease in the shared environment (2). Blastomyces dermatitidis is a dimorphic fungus with two distinct forms, yeast and mycelial forms, which often correspond to saprophytic and parasitic phases, respectively. Conidia (spores) that convert to yeast are infectious to humans. The disease may affect people with weakened immune systems, such as those with human immunodeficiency virus (HIV) infection or who have had an organ transplantation, thus the course and prognosis are determined by the immunological response of patients. Men are more likely to be affected than women, but recent series have shown no specific -sex, -age, -race, -occupational predilection or seasonal variation. The incubation period is $1-3$ weeks $(3,4)$.

The clinical spectrum of blastomycosis is varied, including asymptomatic infection, acute or chronic pneumonia, and extrapulmonary disease. If the infection spreads from the chest, lesions develop in many organs, most commonly in the skin, bones and central nervous system. Mucous membranes are rarely involved. Pulmonary lesions are usually asymptomatic, but they may be associated with fever, chest pain, cough and hemoptysis similar to pulmonary tuberculosis. Pulmonary lesions may resolve spontaneously, but they may also result in cavity formation with lung abscess. In most cases, other organs are also affected. Bone lesions are consistent with osteomyelitis. Lesions of the genital system are more common in males (5). If untreated, the disease frequently disseminates and often progresses to death.

In primary skin blastomycosis, after inoculation, an erythematous, indurated plaque, with firm border ulcerations and associated regional lymphangitis and lymphadenopathy usually appears in 1-2 weeks.
The condition shows a strong tendency towards spontaneous recovery. (6). When the infection spreads from the chest, one or many skin lesions may be present as papule or nodule that may ulcerate and discharge pus. These show a tendency for central scarring, they become serpiginous, with raised and warty borders and miliary abscesses containing yeast. Some patients may also present with confluent nodules and abscesses. The diagnosis of the skin lesions is made by direct microscopy of skin samples (e.g., pus, scrapings) with $10 \%$ potassium hydroxide mount and confirmed by culture or biopsy. Tissue biopsy of the skin or other organs may be required in order to diagnose extra-pulmonary disease. The best way to diagnose the infection is to perform a fungal culture (7). Histopathological analysis provides indentification of all the dimorphic fungi. However, this can be complicated by the fact that in some cases they can be morphologically atypical or sterile (8). In the tissues, $B$. dermatitidis produces characteristic thick-walled, rounded, refractile, and spherical budding yeasts with broad-based buds. On histology, skin lesions associated with bloodstream dissemination, may show pseudoepitheliomatous epidermal hyperplasia, intra- and subepidermal polymorphonuclear abscesses, and granulomatous infiltrates with Langhans giant cells, which may contain round or oval organisms in the dermis. Nonspecific granulomatous infiltrates - abscesses may also be seen (9). The laboratory features are non-specific, but may include raised erythrocyte sedimentation rate, leukocytosis, anemia, hyperglobulinemia and a raised IgE level [10].

Differential diagnosis includes: tuberculosis, leprosy, gangrenous pyodermia, other deep mycoses, squamous cell carcinoma, drug reactions resulting from bromoderma and iododerma. Of the available antimycotic drugs, itraconazole $200 \mathrm{mg} /$ day is probably the most effective, but at least $400 \mathrm{mg} /$ day is recommended initially (10). Ketoconazole 400-600 $\mathrm{mg} /$ day, is an alternative therapy, while amphotericin $\mathrm{B}, 15-30 \mathrm{mg} /$ day, during 10 weeks, should be used in the treatment of disseminated forms of blastomycosis (11). If untreated, the disease takes a chronic course with remissions and exacerbations. Modern treatment is effective, providing a more favourable prognosis of the disease (12). 


\section{Case report}

We present a 46-year-old, non-atopic HIV-negative woman from Doboj, Republic of Srpska, Bosnia and Herzegovina, who was referred to the Department of Dermatovenereology, Clinical Center Banja Luka, Republic of Srpska, Bosnia and Herzegovina, with a 3-month history of an erythematous, large indurated inflamed area on the upper arm. The condition was asymptomatic, immediately following surgical excision of a small tumor in June 2011. According to anamnestic data, the patient had a small, solid brownish skin papule, the size of a grain of rice on the upper left arm. The lesion was at least 20 years old, but suddenly and unexpectedly, itchy redness appered around the tumor and surgical excision was recommended. The histological finding revealed acanthosis and papillomatosis of the epidermis and inflammatory changes in the subepidermal stroma. Histological diagnosis was inflamed dermal papillae. After surgical excision, wound was impaired and it became inflamed. A few days later, the patient developed a fever, irritability and skin tenderness. Staphylococcus aureus was recovered from the lesion, but direct mycological examination and mycological cultures were negative. From June to August 2011, the patient was treated in Doboj with systemic antibiotics, local antibiotics and antiseptics. Due to persistence and spreading of inflammation, the patient was referred to our institution. On admission, the patient presented with a large, soft, fluctuating, erythematous, infiltrated plaque with a granular, wet surface and periferal satellite papules that accuminated into large, spreading nodules.

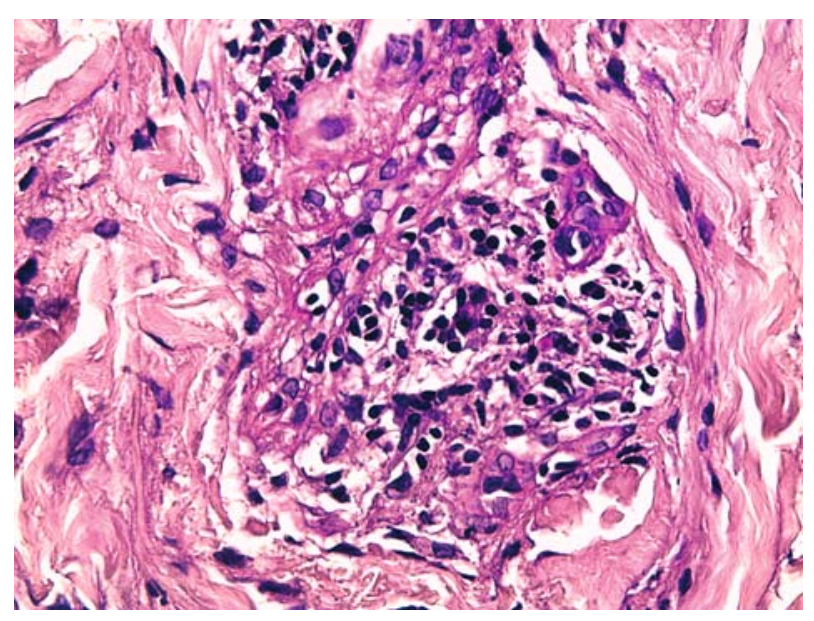

Figure 1. Abscess-like formation with plenty of eosinophils and neutrophils (PAS x 200)
Bacteriological examination: routine wound swabs taken for bacteriological culture were all sterile.

Direct mycological examination of skin samples and sputum in potassium hydroxide mounts and repeated cultures including for Candida were negative.

Baseline laboratory studies included complete blood count, erythrocyte sedimentation rate, urinalysis, C-reactive protein, fibrinogen, aspartate aminotransferase, alanine aminotransferase, lactate dehydrogenase, gamma-glutamyl transpeptidase, serum protein electrophoresis, serum electrolytes, glucose, blood urea nitrogen and creatinine, serum immunoglobulins which were within normal limits except for elevated total serum cholesterol $7.9 \mathrm{mmol} / \mathrm{l}$ (normally).

Other relevant findings, such as ultrasound of the upper abdomen and armpits, chest X-ray, and X-ray of the left upper arm were normal.

Histological finding of the first skin biopsy taken in August 2011 revealed a moderate epidermal hyperkeratosis, pronounced acanthosis and exocytosis of neutrophils and eosinophils in the overlying epidermis. The dermis layer was edematous, with papillary dermal vessels showing ectasia, mixed inflammatory cell perivascular infiltrates with prominent number of eosinophils, neutrophils and polymorphonuclear abscess like formations (Figure 1). Occasionally, there were areas of collagen degeneration with some eosinophils present between collagen fibres. Periodic acid-Schiff staining (PAS) demonstrated focal presence of broad-based budding yeasts, staining pink, appearance typical for $B$. dermatitidis in skin biopsies (Figures 2 and 3).

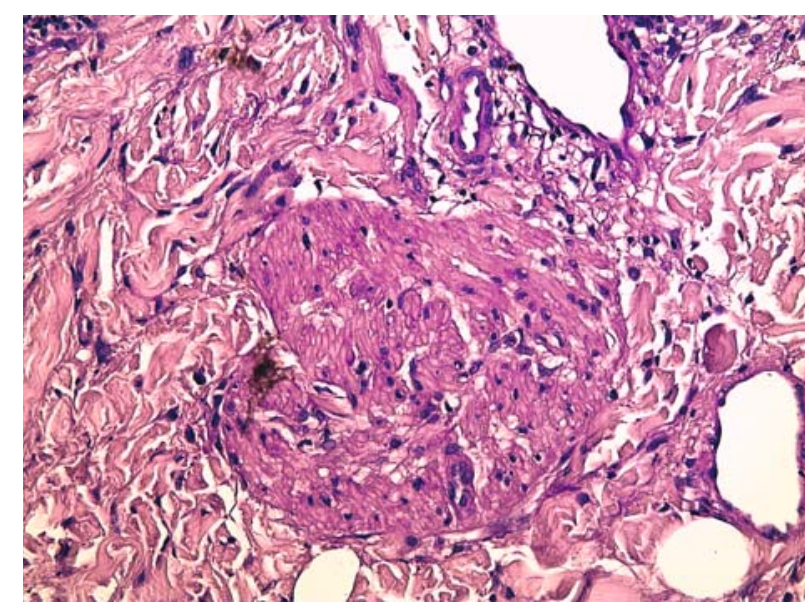

Figure 2. Dermal granuloma: focal presence of budding yeasts in the dermis (PAS x 200) 


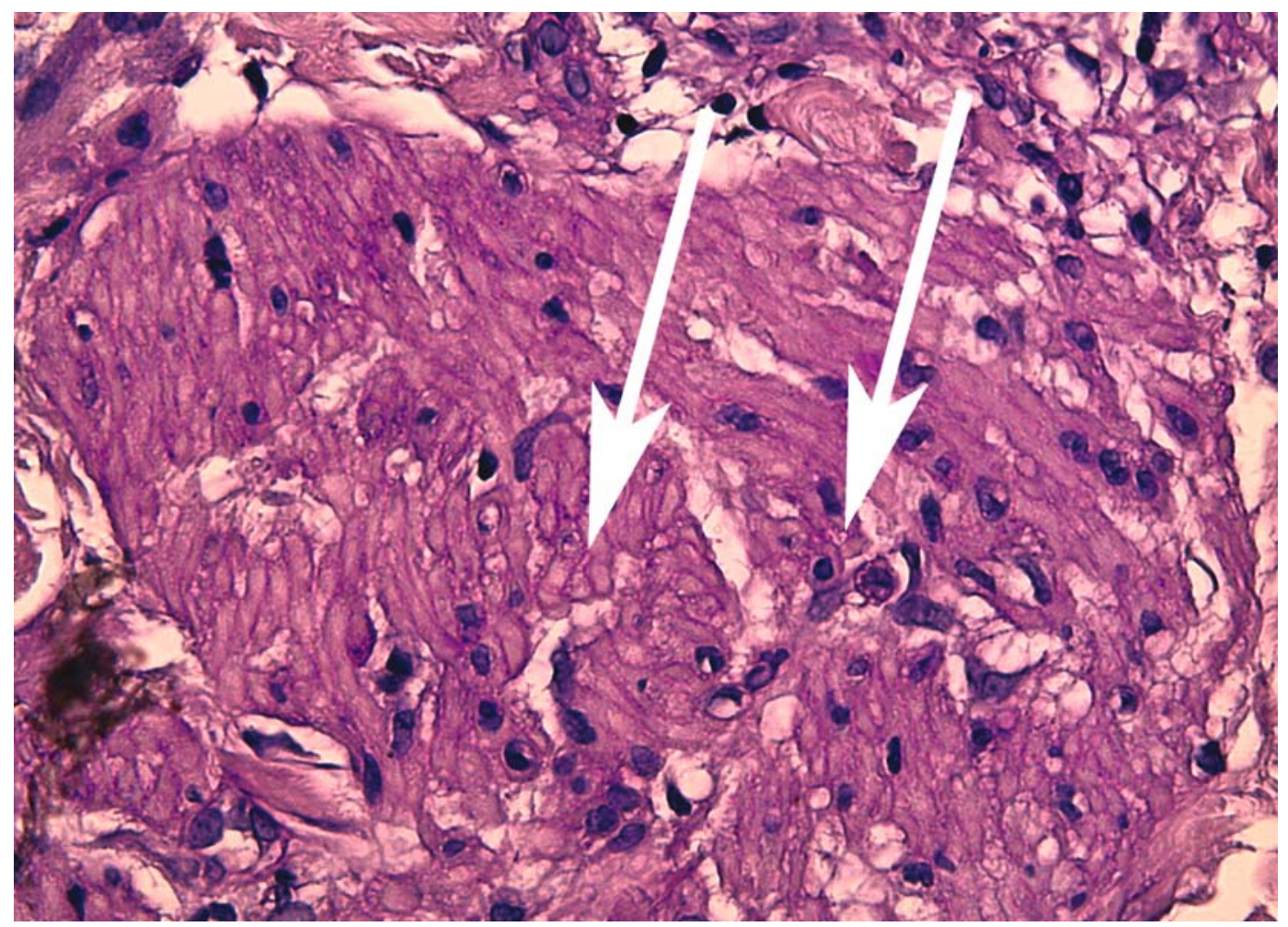

Figure 3. High power view of Blastomyces dermatitidis yeast inside and outside the giant cells (indicated by an arrows) (PAS x 400)

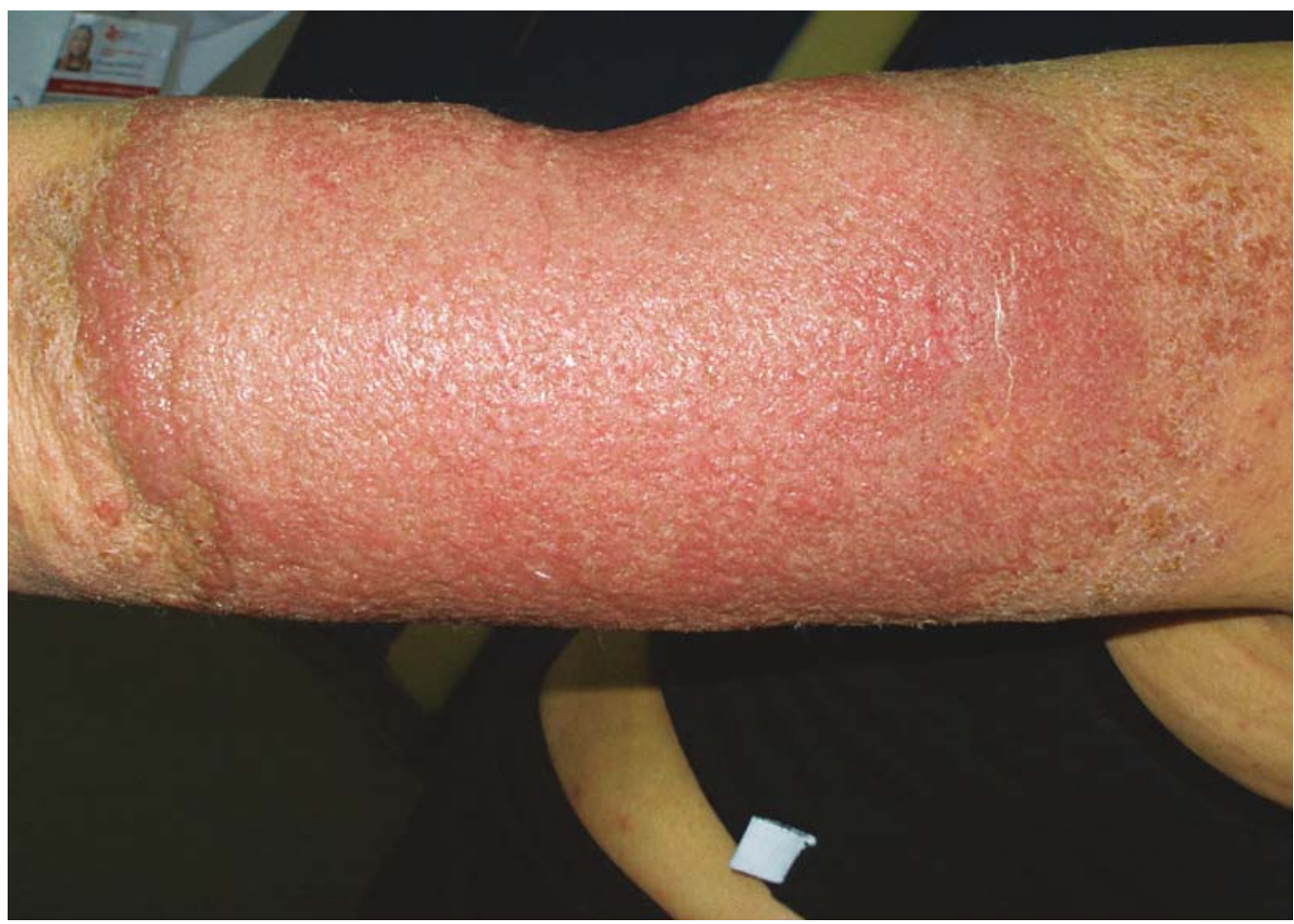

Figure 4. Skin lesion after three months of therapy 


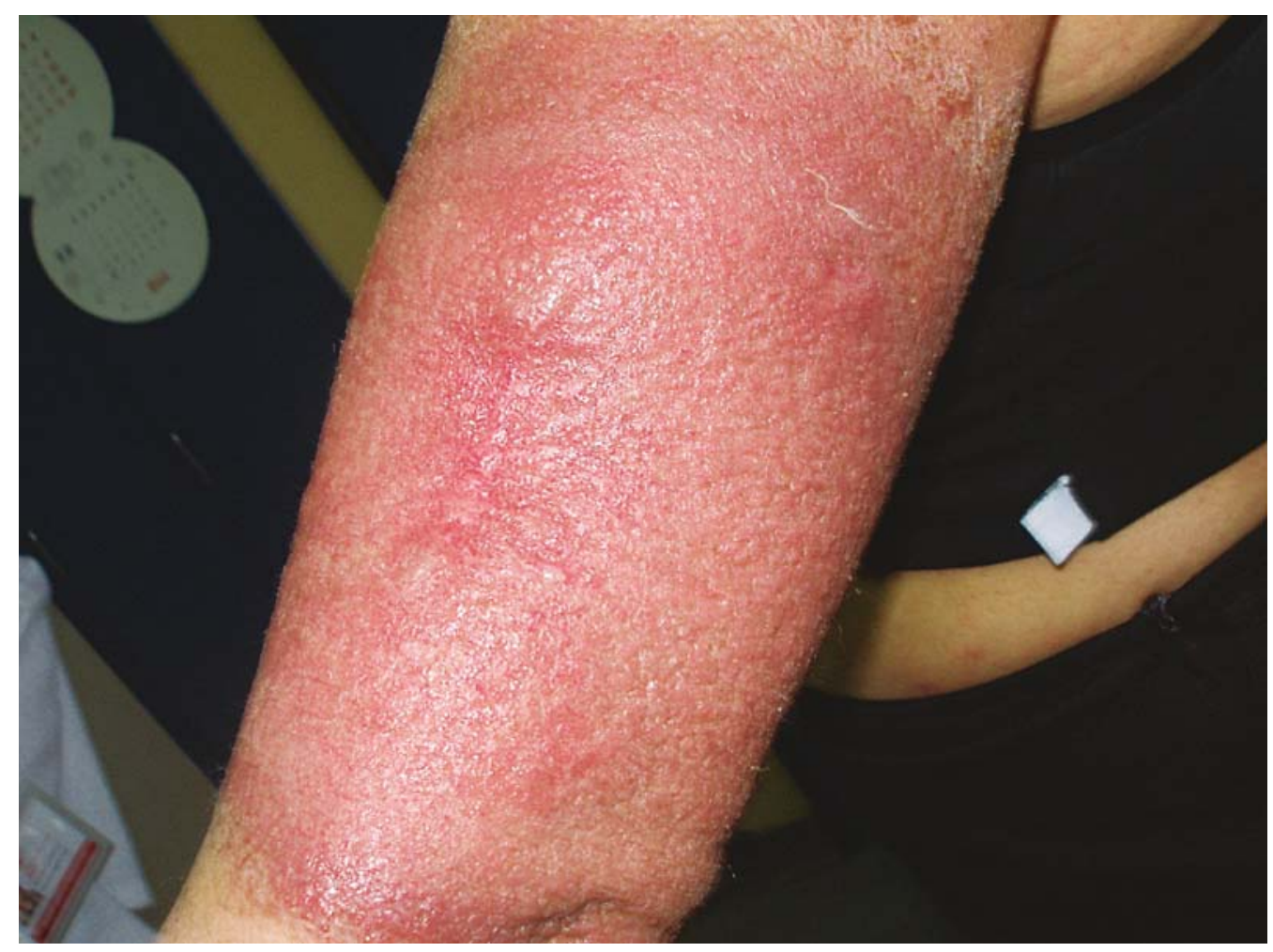

Figure 5. Skin lesion after four months of therapy

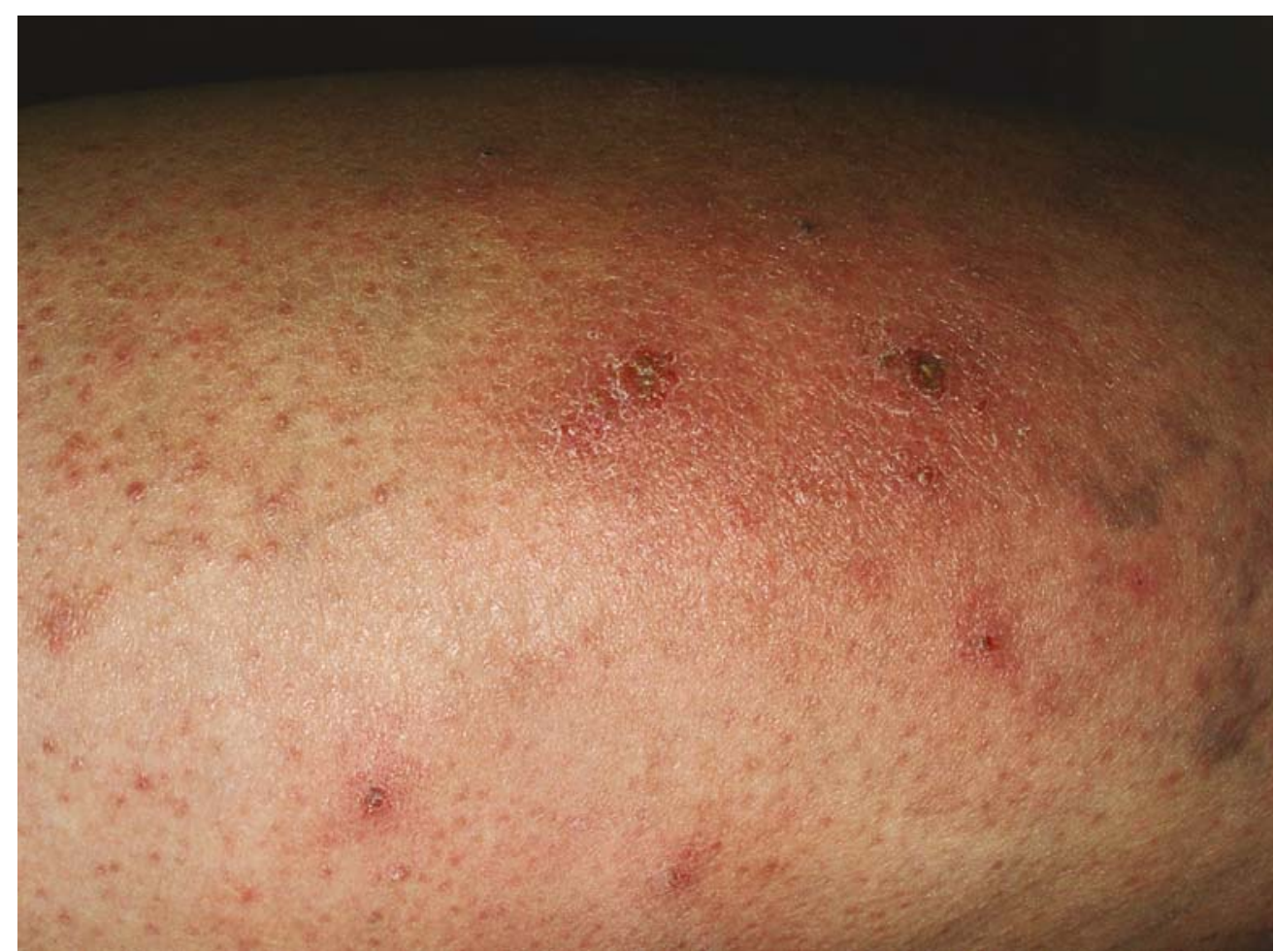

Figure 6. Disseminated skin lesions 


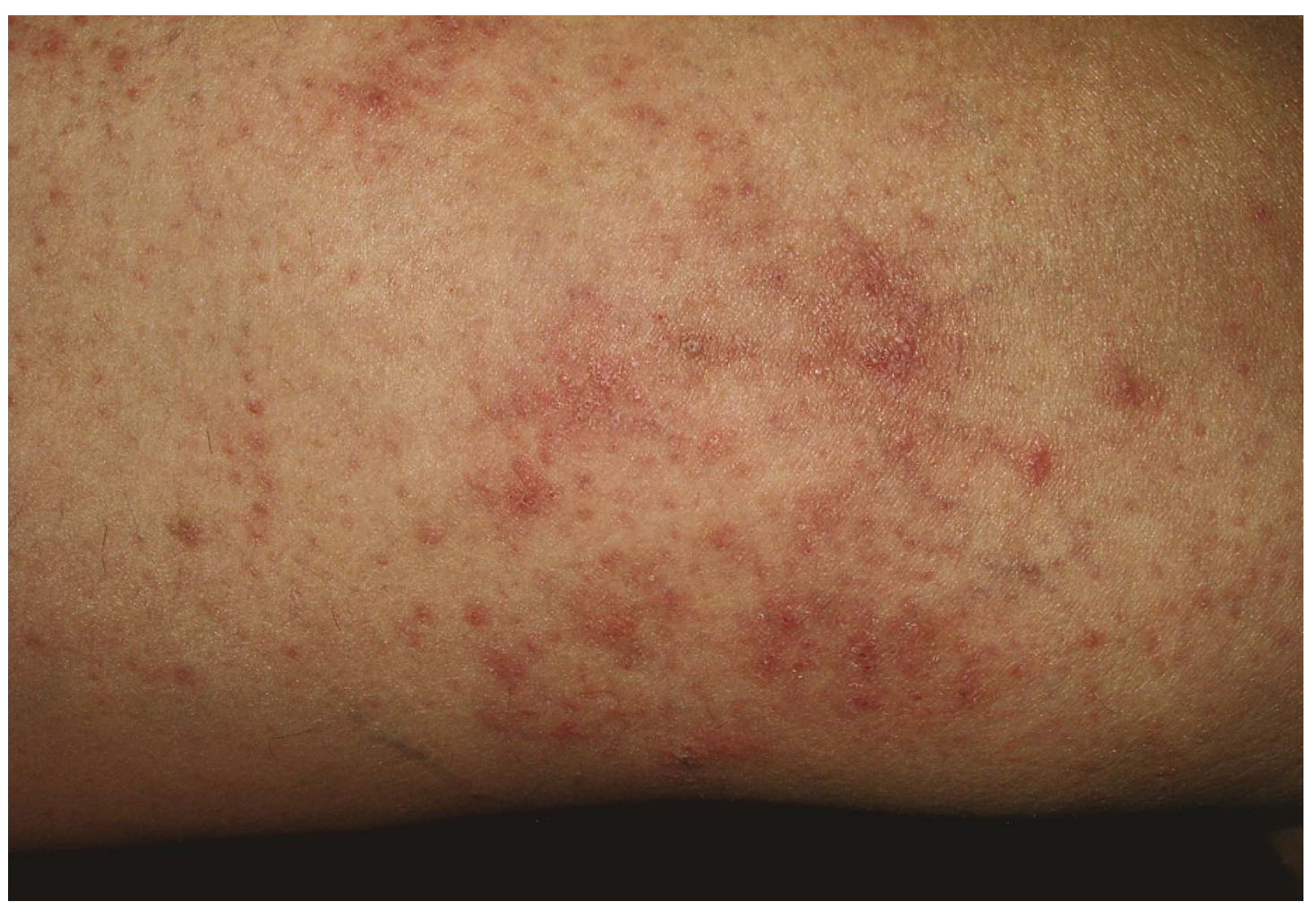

Figure 7. Disseminated small papules

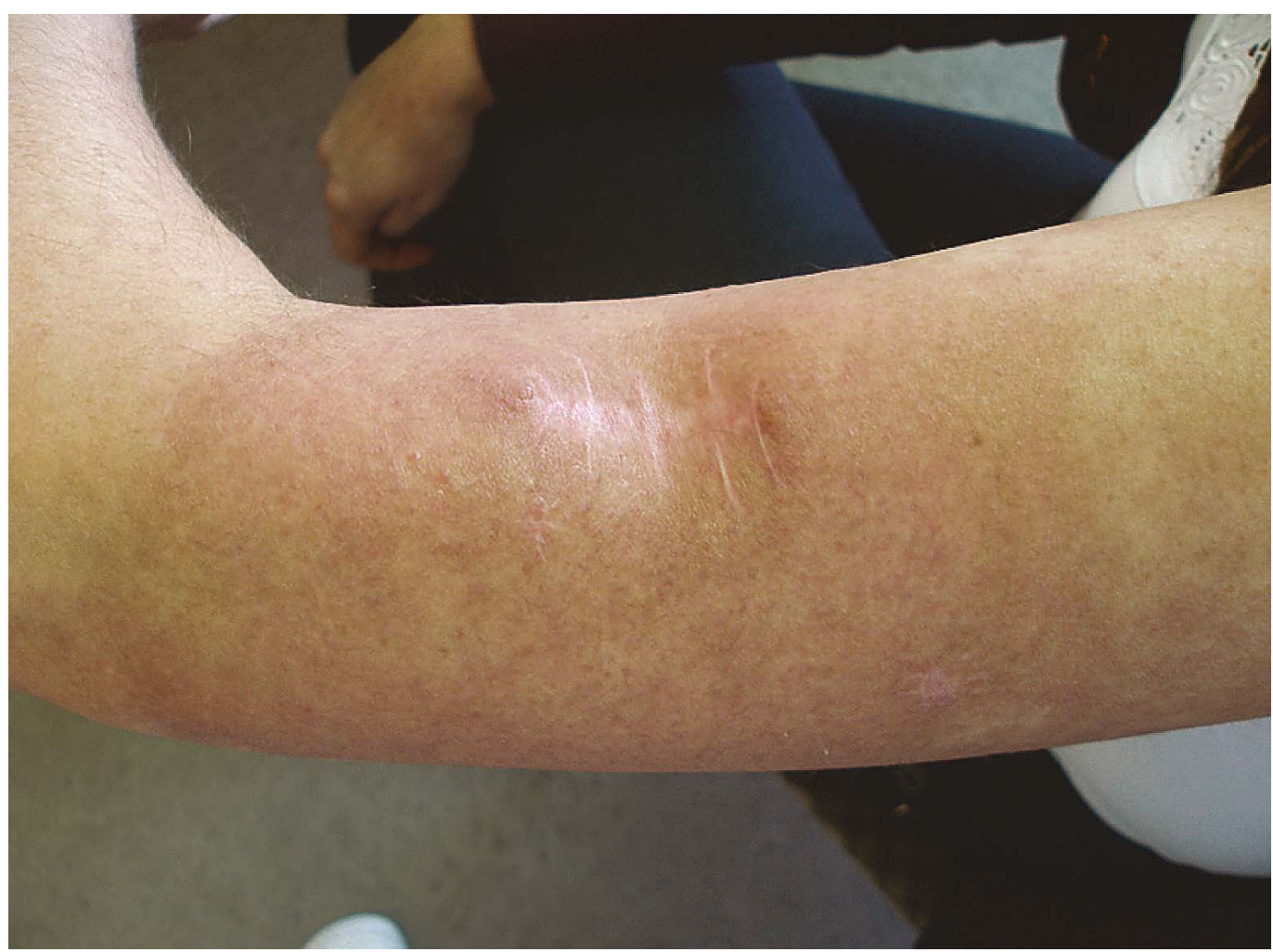

Figure 8. Skin lesion (lateral aspect of the arm) after ten months of therapy 


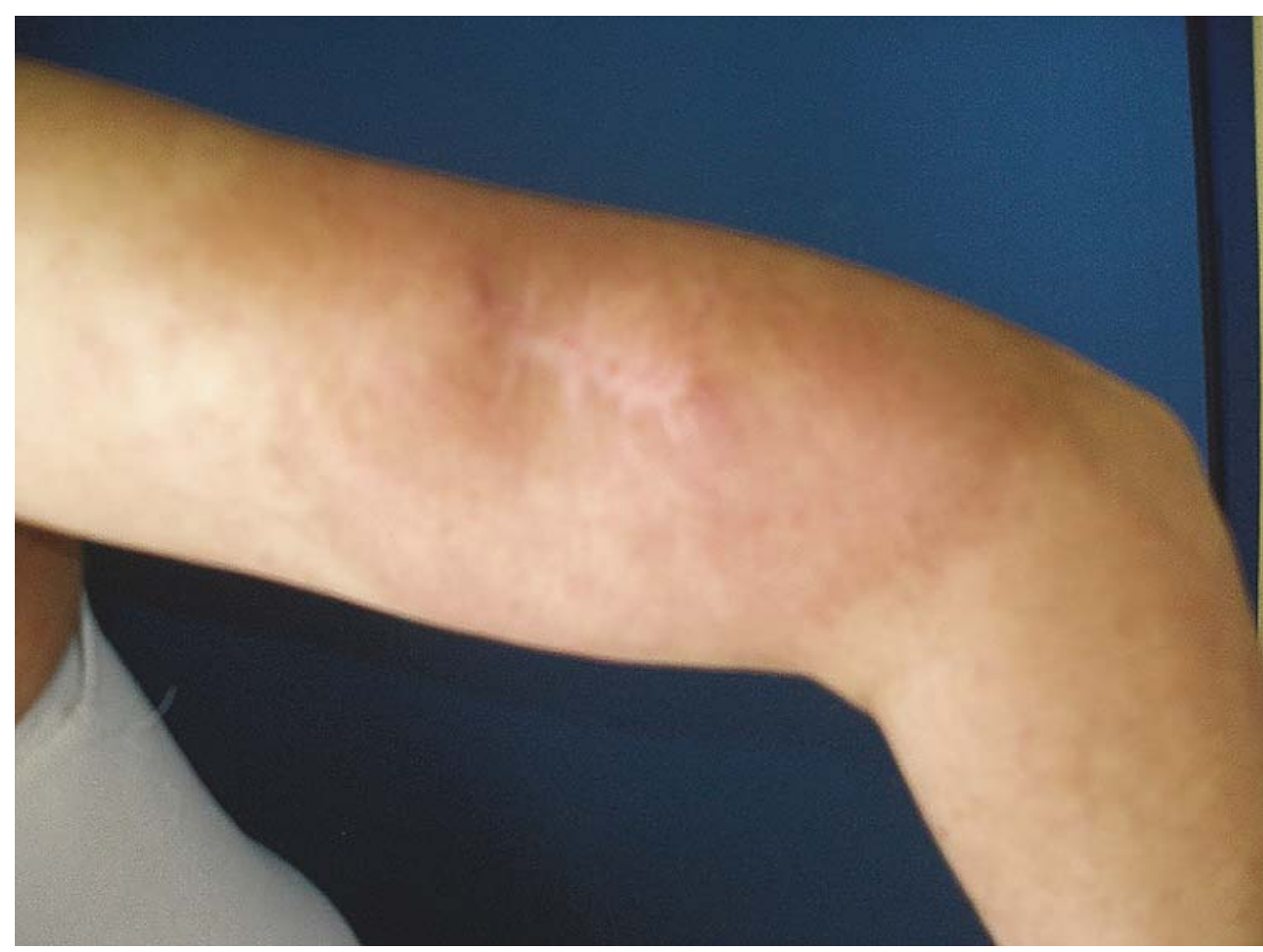

Figure 9. Skin lesion (antero-lateral aspect of the arm) after ten months of therapy

Itraconazole therapy was initiated with at a dose of $2 \times 100 \mathrm{mg} /$ day. After three months of therapy, due to poor therapeutic response (Figure 4) the skin biopsy was repeated and once again, the histological finding revealed thick-walled, rounded, budding cells with broad-based buds that stained pink with PAS. We consulted our colleagues from the Clinic of Dermatology, Military Medical Academy in Belgrade, and the dose of itraconazole was increased to $2 \times 200$ $\mathrm{mg} /$ day during the next three months (Figure 5). In this period, the patient exhibited papules and itching papulopustules disseminated over the upper limbs and trunk, which were recognized as "id" reaction (Figures 6 and 7), and short-term therapy with low-dose methylprednisolone was temporarily administrated. After the treatment, there was a complete regression of skin lesions on the trunk. After seven months of itraconazole therapy, the itraconazole dose was reduced to $2 \times 100 \mathrm{mg}$. The last examination in our hospital was done ten months after the initiation of itraconazole. Further improvement was established (Figures 8 and 9). All control laboratory tests performed monthly were normal. The next examination was scheduled for September 2012.

\section{Discussion}

After exlusion of pulmonary blastomycosis and other organ involvement, the diagnosis of primary inoculation cutaneous blastomycosis was made based on clinical presentation and histopathology finding. The finding of broad-based budding yeast inside and outside the giant cells was very important for making the diagnosis of blastomycosis. Similarly to our case, blastomycosis presenting as a nonhealing wound was reported by Owen et al. (13). Primary cutaneous blastomycosis is very rare. Several case studies have reported on direct cutaneous inoculation of blastomycosis, although in the case reported by Gray NA and Baddour LM, the patient was inoculated after being struck by a projectile while performing yard work (14). The incidence of infections tends to be highest in rural areas and in agricultural workers (8). The diagnosis is confirmed by culture or biopsy (8). Our patient lives in a rural area and the diagnosis was established by identifying the characteristic broad-based bud yeast in the tissue. Itraconazole was introduced because it appeared to be effective in most cases and it can be taken orally (8). 
Blastomycosis is an endemic mycosis that occurs predominantly in North America, NorthCentral United States and provinces of Canada. The greatest number of cases is recorded in the Mississippi Valley (15). One retrospectie analysis, reviewed records of 123 patients treated for blastomycosis at the University of Mississippi Medical Center from January 1980 through May 2000. There were 87\% of patients with pulmonary, $20 \%$ with cutaneous, $15 \%$ with bone, and 3\% with CNS involvement. Proportionally to the pattern of patients admitted to the University of Mississippi Medical Center, there was a clear predominance of black males among patients with blastomycosis, followed by black females. White females constitute the sex/ethnic group least affected by this fungal disease (16). During January through March 2006, twenty-one laboratory confirmed cases of blastomycosis were reported among residents of an endemic area in NorthCentral Wisconsin; a striking increase compared to previous years. Epidemiologic features, signs and symptoms of Blastomyces dermatitidis infection were analyzed among 46 reported (1999-2005) and 21 possible outbreak case. Results of this investigation of a large non-rural outbreak of blastomycosis suggest that bioaerosol hazards may exist near yard waste collections and composting facilities, especially where pine tree litter is present, in Blastomyces dermatitidis endemic areas (17). Blastomycosis is also endemic in some parts of Africa. Clinical differences between the African and North American isolates were noted. The African isolate presents with different types of skin lesions, less frequently involves the central nervous system and more frequently involves bones (18). The known African cases of blastomycosis are presented from 1987, including thirteen previously undescribed cases. This brings to a total number 81 of cases known to have occurred in Africa (18). The question whether the disease in Africa is the same in all respects as that in North America stands; the age and sex distribution of patients is similar. Minor differences in the clinical features relate particularly to the type of skin lesions; bone involvement is more frequent, and central nervous system involvement is less requent in African patients (19). The disease is very rare in China and also commonly misdiagnosed, often as cancer or other infectious disease (20).
The prevalence of the disease among children in endemic regions ranges from $2-11 \%$, and it is extremely rare in children under one year of age (21). Updated guidelines by the Infectious Diseases Society of America are available to aid clinicians in the management of various forms of blastomycosis (22).

Blastomycosis has a significant morbidity and mortality, and in unsuspected atypical, or asymptomatic cases, the skin lesions may be the key to successful diagnosis and treatment (23).

Although uncommonly diagnosed, it is an important fungal infection in the South-Central and Midwestern United States. In endemic areas, blastomycosis appears in the differential diagnosis of many inflammatory systemic diseases, particularly pulmonary, post-traumatic skin, soft-tissue, bone or central nervous system infections $(18,19)$.

\section{Conclusion}

Blastomycosis is rarely encountered in Europe (24). Within the last twenty years, we have identified only one case of blastomycosis, despite a large number of patients refered to our institution. The diagnosis, however, was not confirmed by culture. The difficulty of isolating Blastomycosis dermatitidis from skin lesions has already been reported (24).

\section{References:}

1. Chapman SW, Dismukes WE, Proia LA, Bradsher RW, Pappas PG, Threlkeld MG, et al. Clinical practice guidelines for the management of blastomycosis: 2008 Update by the Infectious Diseases Society of America. Clin Infect Dis 2012;45(12):1801-12. 2. Savio J, Muralidharan S, Macaden RS, D'Souza G, Mysore S, Ramachandran P, et al. Blastomycosis in a South Indian patient after visiting an endemic area in USA. Med Mycol 2006;44(6):523-9.

3. Chapman SW, Bradsher RW, Campbell GD, Pappas PG, Kauffman CA. Practice guidelines for the management of patients with blastomycosis. Infectious Diseases Society of America. Clin Infect Dis 2000;30(4):679-83.

4. Pappas PG. Blasomycosis in the immunocompromised patient. Semin Respir Infect 1997;12(3):243-51.

5. Moris SK, Brophy J, Richardson SE, Summerbell R, Parkin PC, Jamieson F, et al. Blastomycosis in Ontario, 1994-2003. Emerg Infect Dis 2006;12:274-9.

6. Gray NA, Baddour LM. Cutaneous inoculation blastomycosis. Clin Infect Dis 2002;34:44-9.

7. Cecchi R, Bartoli L, Brunetti L, Pavesi M. Blasomycosis-like pyoderma in association with recurrent vesicular hand eczema: Good response to acitretin. Dermatol Online J 2011;17(3):9. 8. 10. Hay RJ, Ashbee HR. Mycology. In: Rook's Textbook of Dermatology. $6^{\text {th }}$ ed. Tony Burns, Stephen Breathnach, Neil Cox, Christopher Griffiths 
eds. Oxford: Blackwell Publishing Ltd; 2010. pp. 36.1-92.

9. Lester RS, DeKoven JG, Kane J, Simor AE, Krajden S, Summerbell RC. Novel cases of blastomycosis acquired in Toronto, Ontario. CMAJ 2000;163:1309-12.

10. Cerullo L, Zussman J, Young L. An unusual presentation of blastomycosis like pyoderma (pyoderma vegetans) and a review of the literature. Cutis 2009;84(4):201-3.

11. McKinnell JA, Pappas PG. Blastomycosis: new insights into diagnosis, prevention, and treatment. Clin Chest Med 2009;30:227-39.

12. Finn MJ, Stiles J, Krohne SG. Visual outcome in a group of dogs with ocular blastomycosis treated with systemic antifungals and systemic corticosteroids. Vet Ophtalmol 2007;10(5):299-303.

13. Owen WR, Thurs K, Kim DS. Blastomycosis presenting as a nonhealing wound. Adv Skin Wound Care 2012;25(7):321-3. 14. Gray NA, Baddour LM. Cutaneous inoculation blastomycosis. Clin Infect Dis 2002;34:44-9.

15. Bradsher RW, Chapman SW, Pappas PG. Blastomycosis. Infect Dis Clin North Am 2003;17:21-40.

16. Lemos LB, Guo M, Baliga M. Blastomycosis: organ involvement and etiologic diagnosis. A review of 123 patients from Mississippi. Ann Diagn Pathol 2000;4(6):391-406.

17. Pfister JR, Archer JR, Hersil S, Boers T, Reed KD, Meece JK et al. Non-rural point source blastomycosis outbreak near a yard waste collection site. Clin Med Res 2011;9(2):57-8.

18. Carman WF, Frean JA, Crewe-Brown HH, Culligan GA, Young CN. Blastomycosis in Africa. A review of known cases diagnosed between 1951 and 1987. Mycopathologia 1989;107:25-32.

19. Bariola JR, Perry P, Pappas PG, Proia L, Shealey W, Wright PW, et al. Blastomycosis of the central nervous system: a multicenter review of diagnosis and treatment in the modern era. Clin Infect Dis 2010;50(6):797-804.

20. Zhao TM, Gao J, She DY, Chen LA. Blastomycosis in China: a case report and literature review. Chin Med J 2011;124(24):4368-71.

21. Walsh CM, Morris SK, Brophy JC, Hiraki LT, Richardson SE, Allen UD. Disseminated blastomycosis in an infant. Pediatr Infect Dis J 2006;25(7):656-8.

22. Smith JA, Kauffman CA. Blastomycosis. Proc Am Thorac Soc 2010;7(3):173-7.

23. Dhamia A, D'Souza P, Salgia P, Meherda A, Kothiwala R. Blastomycosis presenting as solitary nodule: A rare presentation. Ind J Dermatol 2012;57(2):133-5.

24. Chodorowska G, Lecewicz-Torun B. Long-term observation of a case of cutaneous blastomycosis in Poland treated with fluconazole. Mycoses. 1996; 39:283-7

\section{Blastomikoza kože - prikaz slučaja}

\section{Sažetak}

Uvod: Blastomikoza je retka hronična granulomatozna supurativna sistemska mikoza koju izaziva Blastomyces dermatididis i koja se u najvećem broju slučajeva manifestuje kao primarno oboljenje pluća. Primarna blastomikoza kože je retka i uglavnom se javlja kao infekcija u laboratoriji, obdukcijskoj sali, ili posttraumatski. Kada se javlja kod osoba sa oslabljenim imunitetom kao što su inficirani virusom humane imunodeficijencije (eng. Human immunodeficiency virus - HIV) ili nakon transplantacije organa, može se smatrati oportunističkom infekcijom. Period inkubacije je od jedne do tri nedjelje. Kožne lezije su obično asimptomatske; mogu se javiti u širokom spektru kliničkih varijacija u vidu: hiperkeratotičnih nodula, vegetantnih plakova, ulceracija sa manjim pustulama na marginama, vezikulopustuloznom ili nodularnom obliku. Dijagnoza se postavlja na osnovu patohistološkog nalaza i identifikacije uzročnika kulturom. Bolest se u Evropi javlja retko: uglavnom u vidu sporadičnih slučajeva; češća je u nekim delovima Severne Amerike i Kanade.

Prikaz slučaja: Prikazujemo bolesnicu starosnog doba 46 godina, iz Doboja, sa blastomikozom kože na levoj nadlaktici koja se javila neposredno nakon hirurške ekscizije izrasline na koži u junu mesecu 2011. godine. Tumor veličine zrna pirinča, lokalizovan na sredini nadlaktice pacijentkinja je imala prethodnih 20 godina, a hirurška ekscizija je preporučena zbog crvenila i svraba kože u okolini tumora. U patohistološkom nalazu ekscidirane promene opisuje se papilomatozna promena sa akantozom, papilomatozom epiderma i zapaljenskim promenama subepidermalne strome... dijagnoza: papilloma cutis inflamatum.

Rana nakon hirurške ekscizije nije zacelila već se inflamirala i širila uz pojavu povišene temperature koju je pacijentkinja imala pet dana. U brisu uzetom sa kožne promene izolovan je Staphyllococus aureus. Kultura brisa na kvasnice je bila negativna. Od juna do avgusta meseca 2011. godine pacijentkinja je lečena u nadležnim ustanovama u Doboju sistemskim antibioticima, lokalnim antibioticima, antisepticima. Zbog perzistiranja i širenja inflamacije na ruci upućena je u našu ustanovu. Pri prvom pregledu u našoj klinici (avgust 2011. godine) registrovan je: opsežan meki, fluktuirajući, eritematozni, infiltrovani plak, granulozne, izrazito secernirajuće, vlažne 
površine uz salelitske noduse po periferiji. U brisu uzetom sa promene nisu nađene patogene bakterije; mikološkim mikroskopskim pregledom nativnog preparata i kulture u brisu promene na koži i sputumu nisu nađeni gljivični elementi.

Patohistološki pregled: U patohistološkoj analizi isečka uzetog sa promenjene kože, rađenoj avgusta 2011. godine, epidermis je akantotičan i pokazuje izraženu hiperplaziju; na površini epidermisa nalazi se umereno debeo sloj hiperkeratoze, a na više mesta duž epidermisa upalni infiltrat građen od neutrofilnih i eozinofilnih granulocita koji se širi između samih epitelnih ćelija; dermis je edematozan, sa edematoznim i dilatiranim dermalnim papilama koje sadrže dilatirane i krvlju prepunjene krvne sudove, te perivaskularne infiltrate građene od mešovitih zapaljenskih ćelija u kojima osim limfocita dominiraju neutrofilni i eozinofilni granulociti; mestimično je prisutna degeneracija kolagenih vlakana između kojih se nalazi mnoštvo eozinofilnih granulocita; postoji i izvestan broj histiocita sa fagocitovanim hemosiderinskim pigmentom; na pojedinim mjestima fokusi zapaljenja grade apscesoidne strukture. Specijalnim periodic acid-schiff (PAS) bojenjem, na više mesta na površini epidermisa kao i fokalno na rubovima dermisa uočavaju se široke spore karakteristične za blastomikozu.

Svi rezultati laboratorijskih i ostalih relevantnih analiza bili su u granicama fizioloških vrednosti: kompletna krvna slika, osnovne biohemijske analize, antiabdomena i obe aksile, rendgenski snimak pluća i leve nadlaktice.

Dijagnoza: Nakon isključenja zahvatanja pluća i ostalih organa, dijagnoza blastomikoza kože postavljena je na osnovu anamneze, kliničke slike i patohistološkog nalaza. Lečenje: $U$ terapiju je uključen itrakonazol u dnevnoj dozi od 2 x $100 \mathrm{mg}$ tokom 3 meseca. Zbog slabog terapijskog odovora, ponovljena je biopsija kože: nalaz koji je identičan sa analizom prvobitno uzetog bioptata. Posle konsultacije sa kolegama dermatolozima sa Vojnomedicinske akademije (VMA) u Beogradu, dnevna doza itrakonazola povećana je na 2 x $200 \mathrm{mg}$ naredna tri meseca. $\mathrm{U}$ tom periodu, kod pacijentkinje su se, osim promene na ruci, po koži trupa i ekstremiteta, javile diseminovane papule i papulopustule uz osećaj svraba koji su shvaćeni kao „id“" reakcija; u terapiju je uključen sistemski kortikosteroid (metiprednizolon) $\mathrm{u}$ tri navrata $\mathrm{u}$ kratkom vremenskom periodu. Nakon ove terapije, smanjuju se infiltracija, vlaženje promene na ruci i dolazi do regresije kožnih promena po trupu. Nakon sedam meseci, dnevna doza itrakonazola je smanjena na $2 \times 100 \mathrm{mg}$. Poslednji put je pregledana u našoj ustanovi, deset meseci nakon uvođenja itrakonazola u terapiju, kada je i registovana regresija promene na ruci uz perzistiranje postinflamatornog eritema. Svakog meseca su rađene kontrolne laboratorijske analize koje su bile u granicama referentnih vrednosti: kompletna krvna slika i osnovni biohemijski parametri. Prekid davanja itrakonazola uslediće nakon dvanaest meseci od započinjanja lečenja.

Zaključak: Blastomikoza kože je retko oboljenje u Evropi; javlja se u vidu brojnih kliničkih varijeteta; leči se antifungalnim imidazolskim preparatima; lečenje traje i do 12 meseci.

\section{Ključne reči}

Blastomikoza; Dermatomikoze; Ishod lečenja; Tok bolesti; Itrakonazol 